\title{
Isolation and Identification of Yeasts and Lactic Acid Bacteria from Local Traditional Fermented Camel Milk, Chal
}

\author{
Baratali Zarei Yam ${ }^{1 *}$, Morteza Khomeiri ${ }^{1}$, Alireza Sadeghi Mahounak ${ }^{1}$ and Seid Mahdi Jafari ${ }^{1}$ \\ Department of Food Science and Technology, Gorgan University of Agriculture Sciences and Natural Resources, Gorgan, 49138-15739, Iran
}

\begin{abstract}
The yeasts and lactic acid bacteria in samples of the Iranian traditional fermented camel milk, Chal were identified on the basis of physiological and morphological properties. Yeast species were identified including Pichia. anamala, Pichia. jadinii, Debaryomyces. hansenii, Pichia. guilliermondii, Kluyvermyces. marxianus, Candida. fermentati, Pichia. ciferrii, Torulospora. delbrueckii, Candida. versatilis, Kluyvermyces. lactis, Candida. kefir, Saccharomyces. pastorianus, Saccharomyces. serevisiae, Candida. friedrichii, Kluyvermyces. polysporus, Rhodotorula. musilaginosa, Candida. lipolytica and Candida. Iusitaniae. All of them could assimilate the glucose and liquefacted the gelatin, but could not production starch, tolerated $1 \%$ acetic acid, growth in the presence of Nacl 16\% (except Debaryomyces. hansenii), anassimilateed the nitrat (except Rhodotorula. musilaginosa). Within the yeasts species, Kluyvermyces. lactis (8.57\%) and Kluyvermyces. marxianus (8.57\%) were the predominant. Also 93 different lactic acid bacteria species were identified including 64 bacilli as lactobicallus and wieselia, 8 cocci, leuconostoc, 11 coccobacili, leuconostoc, lactococcus and wieselia, 2 streptococci, streptoccus and 8 tetrad cocci shapes, pediococci. All isolates fermented galactose, except Lactobacillus delbrueckii subsp. Bulgaricus, Lactobacillus kefir, Lactobacillus viridescens. All the isolates could growth at $37^{\circ} \mathrm{C}$, only Leuconostoc mesenteroides subsp. Cremoris and Leuconostoc paramesenteroides could not growth at $30^{\circ} \mathrm{C}$. This study revealed Chal contained a wide variety of yeasts and lactic acid bacteria.
\end{abstract}

Keywords: Chal; Fermented Camel Milk; Yeast; Lactic acid bacteria; Identification

\section{Introduction}

In many societies, milk is traditionally consumed predominantly in the form of fermented milk. In many arid areas, camels play a central role as milk suppliers and they are either home-consumed or sold [1].

Chal is a white sparkling beverage that has a sour flavour [2]. The chal is prepared by first souring camel milk in a skin bag or ceramic jar. Previously soured camel milk is added to the fresh milk. It is well mixed and each day, for 3 to 4 days, fresh milk is added to the mixture. Eventually the end product must have 3 to 5 times the original volume of chal that was initially added. This is the best ratio for the chal. The ambient temperature is normally between 25 and $35^{\circ} \mathrm{C}$ [3]. In many regions, camel milk and chal are used to treat some diseases and to combat health problems such as dropsy, jaundice, tuberculosis, asthma, anaemia and piles [4]. Due to acidic $\mathrm{pH}$, dairy products are favorable environment for growth of yeasts and LAB [5,6]. The yeasts play usefull effect upon the bacteria due to change in $\mathrm{pH}$ and secretion of biological substance such as vitamins, enzymes, amino acids etc [7]. The yeasts isolated from dairy products are different, but the most frequently described strains belong to the genera Saccharomyces, Kluyveromyces, Debaryomyces, Issatchenkia, Galactomyces, Fellomyces, Pichia and Yarrowia [8-12]. The yeasts occurr in many dairy related products $[13,14]$ and in the human gastrointestinal tract $[15,16]$ and have probiotic potential. Saccharomyces boulardii is the yeast commercialized as probiotic in human medicine [17], but also in several studies strains such as Kluyveromyces lactis, K. marxianus, Isaatchenkia orientalis, S. cerevisiae and Debaryomyces hansenii have shown antifungal, antibacterial, anti-inflammatory and antitumoral activity $[18,19]$.

LAB find increasing acceptance as probiotics which aid in stimulating immune responses, preventing infection by enteropathogenic bacteria, and treating and preventing diarrhea [20]. These bacteria have long been used for changing the aromatic and textural properties of food and for extending the shelf-life of various products such as dairy products [21]. The primary role of $\mathrm{LAB}$ is to ferment available carbohydrates and causing a decrease in $\mathrm{pH}$. The combination of low $\mathrm{pH}$ and organic acids (mainly lactic acid), diacetyl, hydrogen peroxide, and bacteriocins or bactericidal proteins are the main preservation factor in fermented dairy products $[22,23]$. Bacteriocins are considered as safe natural preservatives or biopreservatives.

Isolation and screening of microorganisms from naturally occurring processes have always been the most powerful means for obtaining useful cultures for scientific and commercial purposes. This certainly holds true for lactic acid bacteria (LAB), which are used throughout the world for manufacture of a wide variety of traditional fermented foods. Since they are involved in numerous food fermentations, known to man for millennia, it is assumed that most representatives of this group do not pose any health risk to man, and are designated as GRAS (Generally Recognized as Safe) organisms.

The aim of this study was isolation and identification of yeasts and lactic acid bacteria from the traditional fermented camel milk, Chal in Golestan province of Iran and use this isolates in later studies for operational aims.

\section{Materials and Methods}

\section{Sampling}

A total of 9 sour camel milk (Chal) samples (A to I) were randomly collected from different house holds and retail markets with different

*Corresonding author: Baratali Zarei Yam, Department of Food Science and Technology, Gorgan University of Agriculture Sciences and Natural Resources, Gorgan, 49138-15739, Iran, E-mail:alizarei1662@gmail.com

Received April 01, 2014; Accepted May 14, 2015; Published May 21, 2015

Citation: Yam BZ, Khomeiri M, Mahounak AS, Jafari SM (2015) Isolation and Identification of Yeasts and Lactic Acid Bacteria from Local Traditional Fermented Camel Milk, Chal. J Food Process Technol 6: 460. doi:10.4172/2157-7110.1000460

Copyright: (c) 2015 Yam BZ, et al. This is an open-access article distributed under the terms of the Creative Commons Attribution License, which permits unrestricted use, distribution, and reproduction in any medium, provided the original author and source are credited. 
Citation: Yam BZ, Khomeiri M, Mahounak AS, Jafari SM (2015) Isolation and Identification of Yeasts and Lactic Acid Bacteria from Local Traditional Fermented Camel Milk, Chal. J Food Process Technol 6: 460. doi:10.4172/2157-7110.1000460

Page 2 of 6

sanitation levels in the original container from Golestan province. The areas under investigation were Gonbad, Aghghala and Bandar Torkman cities.

\section{Compositional Analysis}

The Chal samples were analyzed for Fat [24], ash [25], pH, Nacl, Alcohol (after $48 \mathrm{~h}$ fermentation) [26], Protein, TS and Acidity content [27]. All the experiments carried out in three repetitions and means reported.

\section{Isolation and Identification of Yeasts}

One milliliter from each samples was serially diluted in distilled water and spread- plated onto YGC agar (Mirmedia, Iran) to isolate the yeasts. The plates were incubated at $25^{\circ} \mathrm{C}$ for 5 days. Colonies with distinct morphological differences such as colour, shape and size were picked and purified by streaking. The purified isolates were stored on YGC agar slant at $4^{\circ} \mathrm{C}$ under liquid parafin before identification. The colonies were tested and described based on morphological characteristic on Yeast- Mold Agar (YMA) and YM broth as following:

Yeast fermentation base medium containing $2 \%$ one of Carbohydrates (glucose, fructose, galactose, maltose, lactose, sucrose, xylose, arabinose, trehalose, manitol, melezitose and rafinose) as a sole carbon source for testing the assimilation of carbon sources for a month, gas production from carbohydrates $5 \%$ (glucose, fructose, galactose, maltose and lactose) by using durham tube for three weeks, production of extracellular starch compounds, urease test for hydrolyzation activity, growth in the presence of $\mathrm{D}$-glucose (50 and $60 \%$ ) and $\mathrm{NaCl}$ (10 and 16\%), gelatin liquefaction and tolerance of $1 \%$ acetic acid according to Suh et al. [28], and investigation of the assimilation of nitrat, growth in the presence of cycloheximide $(0.1 \%$ and $1 \%)$ with modified method according to Kerry et al. [29] using disk inoculum- solid medium method were achiened. The isolate were identified according to protocol described by Suh et al. [28].

\section{Isolation and Identification of Lactic acid bacteria}

Lactic acid bacteria count in MRS agar media (Liofilchem, 610024, Italy ) determined according to the method described in Compendium of Methods for the Microbiological Examination of food [30]. The LAB isolated on MRS agar after suspending the sample $(10 \mathrm{ml})$ in $90 \mathrm{~mL}$ distilled water and making serial dilutions. The medium was sterilised by heating at $121^{\circ} \mathrm{C}$ for $15 \mathrm{~min}$. the plates were incubated at $37^{\circ} \mathrm{C}$ for 2 days. Colonies with distinct morphological differences such as colour, shape and size were picked and purified by streaking at least three times. The purified isolates were stored on MRS agar slant at $4^{\circ} \mathrm{C}$ in liquid parafin untile required for identification.

The cultures were tested and described for colony and cell morphology on MRS agar and MRS broth, Gram stain and catalase test [31], growth at $15,30,1 \mathrm{nd} 42^{\circ} \mathrm{C}$ anaerobically and at 37 aerobically $[32,33]$, urea and argenin hydrolysis test [34], production of acid from diferent Carbohydrates using media containing $0.8 \%$ yeasts extract, $0.8 \%$ trypton, $1.2 \%$ pepton (from milk), $0.1 \%$ tween, $0.0004 \%$ bromophenol blue as indicator and 2\% carbohydrates [35], Gas production from $2 \%$ glucose and sodium gluconate using durham tube [36], and growth in the presence of 2, 4, 6, 8 and $10 \%$ Nacl carry out according to De Man et al. [37]. In all tests sensitive compounds to heat such as carbohydrates, cycloheximide, yeasts nitrogen base medium, yeasts fermentation base medium were sterilized using $0.23 \mu$ Millipore filter apparatus.

\section{Statistical analysis}

Data were analyzed using SPSS version 10.05-computer program.

\section{Results and Discussion}

\section{Compositional analyses}

Chemical properties of chal given in Table 1.

Our results revealed that the $\mathrm{pH}$ was ranged from 3.8 to 4.5 . Although lower $\mathrm{pH}$ has inhibitory effect on the vegetative cells of pathogenic microorganisms, but it is favorable for growth of yeasts and lactic acid bacteria [38].

Results in Table 2 revealed yeast and moulds and LAB counts in chal samples are high, it can attributed to acidic medium of chal that is favourable for growth of yeasts and lactic acid bacteria.

\section{Identified yeasts}

Yeasts commonly associated with traditional fermented dairy products and have been reported in several studies [39-41]. All the identified strains shown in Figure 1.

Septate hyphae were formed by none of them and Kluyvermyces marxianus, Torulospora delbrueckii, Kluyvermyces lactis, Candida lipolytica and Candida lusitaniae formed ascospores. A part of the detected strains belonged to order Ascomycotina and the rest to order Deuteromycotina - Imperfect yeasts.

The most yeast isolates utilized galactose, fructose and maltose and most of them fermented glucose and fructose. All of isolates assimilated the glucose and liquefacted the gelatin, but starch production, tolerance to $1 \%$ acetic acid, growth in the presence of $\mathrm{NaCl} 16 \%$, septate hyphae and nitrat assimilation were not seen for all, except Debaryomyces hansenii which grown in the presence of $\mathrm{NaCl} 16 \%$ and Rhodotorula musilaginosa assimilated the nitrate. Urea hydrolysis was negative for all isolates except the isolate identified as Rhodotorula musilaginosa. Isolates identified as Pichia anamala, Kluyvermyces marxianus, Candida fermentati, Pichia jadinii, Debaryomyces hansenii, Pichia guilliermondii, Pichia ciferrii, Torulospora delbrueckii, Candida friedrichii, Candida lusitaniae and Candida versatilis could grow in the presence of Glucose $50 \%$ and $60 \%$, and for rest of them were negative. Candida fermentati, Pichia jadinii, Pichia guilliermondii, Candida friedrichii, Candida Kefir, Rhodotorula musilaginosa, Candida lipolytica and Candida lusitaniae could grow in the presence of Cyclohex $0.1 \%$ and $1 \%$, but for rest of them were negative. Ascospore production for Kluyvermyces. marxianus, Torulospora. delbrueckii, Kluyvermyces. lactis, Candida lipolytica and Candida lusitaniae were positive.

From the Chal samples, 35 yeasts species including, 8 Pichia (22.85\%), 8 Kluyvermyces (22.85\%), 10 Candida (28.57\%), 2 Debaryomyces (5.71\%), 2 Torulospora (5.71\%), 4 Saccharomyces (11.42\%)and 1 Rhodotorula (3.50\%) were identified. Among the yeasts species, Kluyvermyces lactis (8.57\%) Kluyvermyces marxianus (8.57\%) were the predominant (Figure 1).

Yeast species including Pichia anamala, P. jadinii, P. guilliermondii, Deb. hansenii, Kluyveromyces polysporus, Kluyveromyces marxianus which were isolated from samples of Chal, were also isolated from dairy products in the previous study $[42,43]$. However Candida fermentati was isolated from Chal only and was n't found previously in dairy products. Kluyveromyces marxianus has previously been isolated from indigenous fermented milk products such as Gariss, suusac, koumiss and kefir $[44,45]$. In the present study, Kl.marxianus was frequently 
Citation: Yam BZ, Khomeiri M, Mahounak AS, Jafari SM (2015) Isolation and Identification of Yeasts and Lactic Acid Bacteria from Local Traditional Fermented Camel Milk, Chal. J Food Process Technol 6: 460. doi:10.4172/2157-7110.1000460

Page 3 of 6

\begin{tabular}{|c|c|c|c|c|c|c|c|c|c|}
\hline Sample Code & A & B & C & $\mathrm{D}$ & $E$ & $\mathrm{~F}$ & G & $\mathrm{H}$ & I \\
\hline Protein \% & 1.0 & 1.0 & 1.2 & 1.1 & 1.5 & 2.2 & 1.3 & 1.5 & 1.4 \\
\hline Fat\% & 2.2 & 2.1 & 2.0 & 1.7 & 1.8 & 1.6 & 2.0 & 1.9 & 1.6 \\
\hline TS\% & 4.0 & 3.9 & 4.1 & 3.7 & 4.0 & 4.6 & 4.1 & 4.0 & 3.8 \\
\hline Ash\% & 0.23 & 0.31 & 0.32 & 0.27 & 0.32 & 0.38 & 0.31 & 0.32 & 0.29 \\
\hline Acidity (D*) & 32.0 & 33.0 & 31.0 & 34.0 & 31.0 & 34.5 & 35.0 & 35.5 & 31.0 \\
\hline $\mathrm{pH}$ & 4.0 & 4.2 & 4.5 & 4.4 & 4.5 & 4.0 & 3.9 & 3.8 & 4.5 \\
\hline $\mathrm{NaCl} \%$ & 0.80 & 0.75 & 0.90 & 0.85 & 0.70 & 0.80 & 0.76 & 0.60 & 0.80 \\
\hline Alcohol\% (w /v) & 0.80 & 0.70 & 0.40 & 0.70 & 0.40 & 0.50 & 0.80 & 0.60 & 0.60 \\
\hline
\end{tabular}

* Dornic

Table 1: Compossition of chal samples.

\begin{tabular}{|c|c|c|c|c|c|c|c|c|c|}
\hline Sample NO. & 1 & 2 & 3 & 4 & 5 & 6 & 7 \\
\hline Yeast and moulds & 4.11 & 4.04 & 3.90 & 4.04 & 3.95 & 4.00 & 4.08 & 4.05 \\
\hline Lactic acid bacteria & 4.58 & 4.51 & 4.44 & 4.14 & 4.04 & 4.46 & 4.32 & 4.08 & 4.25 \\
\hline
\end{tabular}

Table 2: Yeast and moulds and Lactic acid bacteria counts ( $\log \mathrm{Cfu} / \mathrm{ml})$.

isolated and constitutes the dominant yeast microflora of Chal. Yeast growth in Chal is thus probably positively influenced by the metabolic activities of the LAB present. Lactose fremneting Kl.lactis was found to be the predominant yeast species; the precise role of yeasts in Chal requires further study (Figures 2 and 3 ).

\section{Identified LAB}

LAB strains isolated, purified and further identified and differential tests were applied including morphological and physiological characteristics which facilitate the opportunity for identification of the LAB. The identification results were confirmed by the carbohydrates fermentation and assimilation profile obtained in correlation with bergeys manual [46] and also using the manuals of Sharpe [47]; Holt et al. [48]; Garrity et al. [49]; Hardie [50]; Kandler and Weiss [51]; Mundt [52] and Sneath et al. [32].

From the collected samples a total of 93 isolates randomly picked, after the original characterization. The selected isolate gave bluepurple color with gram staining; hence they are all gram positive and catalas negative. 64 of them were found to be bacilli with long/ short and rounded ends, pairs or single cells and these could determine as derivatives of the genus Lactobacillus and Wieselia. The rest of the isolates were cocci with spherical, round or ovoid morphology and appeared mostly as pairs, sigle or forming chains and tetrad shapes, therefore they referred to Lactococcus, Streptococcus, Leuconostoc, Wieselia and Pediococcus genus. Results showed in Figures 2 and 3.

Elgadi et al. [53] showed in cows and goats milk, the counts of streptococci on M17 were higher than those of lactobacilli, whereas the lactobacilli were higher in the camel milk and the ewes milk contained almost the same counts of lactobacilli and streptococci. The results of this study confirmed it as lactobacillus were higher than other lactic acid bacteria species.

Results showed Lactobacillus reuteri, Lactobacillus fermentum, Lactobacillus salivarius, Lactobacillus curvatus, Pediococcus urinaeequi and Lactobacillus animalis could growth in the presence of $10 \%$ $\mathrm{Nacl}$, while all the strains showed proper growth in $2 \% \mathrm{NaCl}$ except isolates identified as Leuconostoc mesenteroides subsp. Cremoris and Lactobacillus helveticus. It was also observed that all isolates fermented galactose, except Lactobacillus delbrueckii subsp. Bulgaricus, Lactobacillus kefir and Lactobacillus viridescens. Growth at $37^{\circ} \dot{\mathrm{C}}$ for all the isolates were positive, while Leuconostoc mesenteroides subsp. Cremoris and Leuconostoc paramesenteroides could not growth at $30^{\circ}$ $\dot{\mathrm{C}}$. Production of $\mathrm{Co}_{2}$ from sodium gluconate for Lactobacillus curvatus and Lactobacillus fermentum were variable and positive respectively, and for rest of them were negative. Mannose, lactose and xylose assimilated by the most of the isolates, whereas only Lactobacillus divergens could assimilate glycerol. There was variation in the utilization of other the carbohydrates sources for different lactic acid bacteria isolated from chal samples. None of the isolates could hydrolize urea. These results are similar to the Bergey's manual of determinative bacteriology $[54,55]$.

From obtained results observed that Lactobacillus plantarum (13\%) and $L b$. hilgardii $(9.78 \%)$ in bacilli, and leuconostoc species (13\%) within cocci shapes are predominant in lactic acid bacteria isolated from chal samples.

These results confirm the predominance of LAB in traditionally fermented camel's milk, as reported by other researchers [56,57] and comparable to those reported in previous studies on fermented milk products in Sudan and neighboring countries [58]. Weissella hellenicus was isolated only from one Chal sample meaning that these bacteria are probably present in low numbers. The species is occasionally detected in dairy products [59] and it is believed that their presence is a result of low sanitary conditions during the handmilking and handling.

Elgadi et al. [53] found that the dominant lactic acid bacteria in milk of different animal species were streptococcus lactis $(34.9 \%)$, lactobacillus fermentum (20.6\%), Lb. plantarum (19.1\%), Strep. Cremoris (14.3\%), Lb. acidophilus (9.5\%) and Leuconostoc lactis (1.6\%). The homofermentative lactobacilli from cow and camel milk were tentavily isolated as Lactobacillus plantarum and Lb. acidophilus, whereas the heteroferementative ones from cows, goats and ewes milk found to be $L b$. fermentum. Also their results revealed the homo fermentative streptococci isolated from all milk samples identified as streptococcus cremoris and streptococcus lactis, whereas the only heterofermentative strain from camel milk was found to be Leuconostoc lactis. Lb. fermentum that isolated from Chal in this study, previously was isolated by Abdel Gadir et al. [19] from cows milk, Although results obtained mostly reported in cereal based fermented dough $[60,61]$.

According to Chandan [62]; Anuradha and Rajeshwari [63]; Gibson and Roberfroid [64], many of the LAB isolated from chal in this study such as Lactobacillus delbrueckii subsp. delbrueckii, Lactobacillus delbrueckii subsp. bulgaricus, Lactobacillus plantarum, Lactobacillus gasseri, Lactobacillus acidophilus, Lactobacillus casei subsp rhamnosus, Lactobacillus casei subsp. paracesei, Lactobacillus reuteri, Streptococcus thermophilus, Lactobacillus fermentum, Lactobacillus brevis, Lactobacillus helveticus and Lactobacillus curvatus classified in 
Citation: Yam BZ, Khomeiri M, Mahounak AS, Jafari SM (2015) Isolation and Identification of Yeasts and Lactic Acid Bacteria from Local Traditional Fermented Camel Milk, Chal. J Food Process Technol 6: 460. doi:10.4172/2157-7110.1000460

Abundance $(\%)$
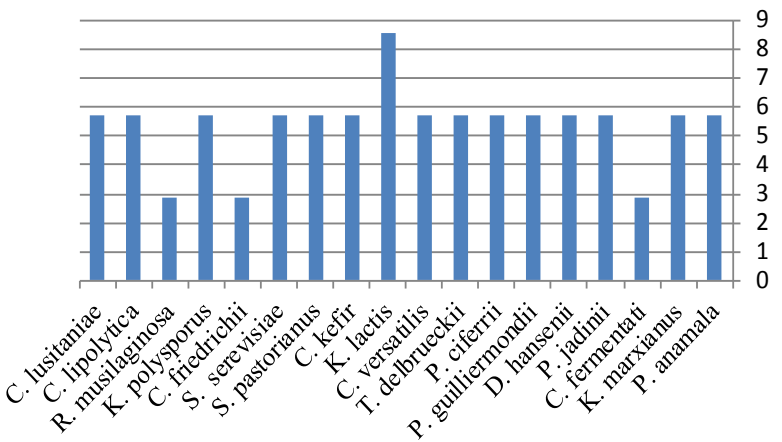

Figure 1: Estimation of yeasts species isolated from Chal samples.

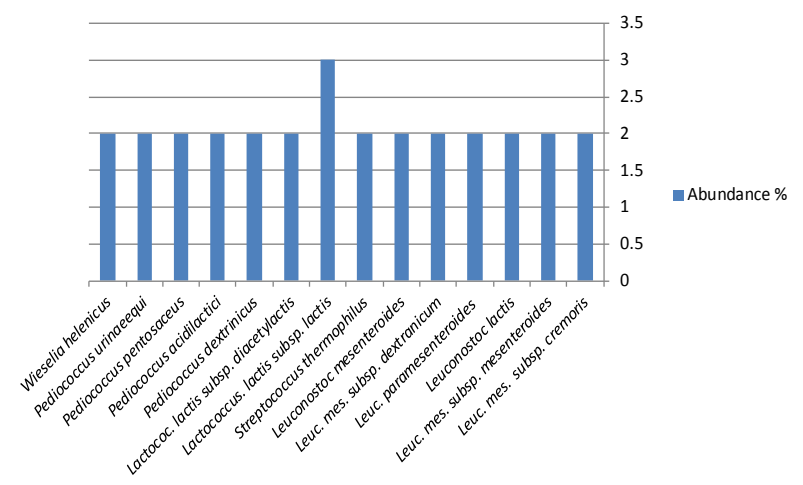

Figure 2: Cocci shape LAB isolated from Chal samples.

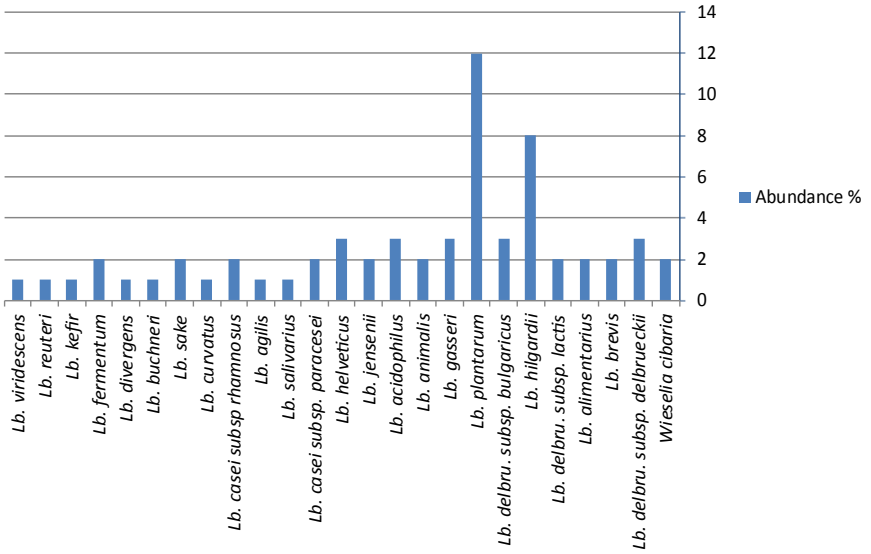

Figure 3: Bacilli shape $L A B$ isolated from Chal samples.

group of probiotic microorganisms, accordingly chal has a potential to considere as a probiotic product.

Ashmaig et al. [9] from Sudanese fermented camel milk (gariss) isolated Lactobacillus plantarum (66.6\% of the gariss isolates), Lactococcus raffinolactis (33.3\%). Lactobacillus animalis, Lactobacillus brevis, Lactobacillus divergens, Lactobacillus rhamnosus, Lactobacillus gasseri, Lactobacillus paracasei, Lactobacillus fermentum, Lactococcus alimentarium and other Lactobacillus species. Many of the mentioned isolated above (in gariss samples) isolated from chal in this study.

Mostly, lactic acid producing bacteria that grow in camel milk are Lactobacilli (Lactobacillus acidophilus) and Streptococci (S. cremoris and S. lactis), which are used as starters in dairy products. More growth of $L$. acidophilus was observed in camel milk as compared to others, as in every camel milk sample L. acidophilus was found. These findings are in accordance with Abu-Tarboush [13], who reported that camel milk provided support to the growth of L. acidophilus.

Although morphological and biochemical characterization based on sugar fermentation pattern is a useful tool for presumptive classification, but may not always provide sufficient basis for the reliable identification of lactic acid bacteria and yeasts, as reported by other researchers [65-67] accordingly, available systems should be combined with genotypic techniques which allowed more accurate identification.

Micro-organisms are important in dairy products. One of the most important groups of acid producing bacteria in the food industry is the Lactic Acid Bacteria (LAB) which are used in making starter culture for dairy products. The proper selection and balance for starter culture is critical for the manufacture of fermented products of desirable texture and flavour. Our results provide some raw data and strain resource for further study involved in probiotic strain selection and starter culture design concerning the industrialization production of traditional fermented milk.

\section{Conclusions}

Thirty five yeast species belonging to 18 genera were isolated and identified from samples of chal. Results showed Chal contained a wide variety of yeasts that are predominanted at Chal after the $48 \mathrm{~h}$ fermentation. Chal was made from raw camel milk, but the presence of yeasts indicates the contamination of the product by air, water or persons who are engaged in the preparation and transportation. This study recommended that increasing the hygienic level in Chal production be effective to decrease the yeast contamination. The present study has showed that the microflora in Chal comprises a combination of LAB and yeasts. The LAB were represented by Lactobacillus, Lactococcus, Leuconostoc, streptococcus, Pediococcus and Weissella, with the most frequently isolated LAB being Lactobacillus plantarum, Lb. hilgardii and leuconostoc species.

Based on the finding of the present study, it is concluded that chal contains wide variety of lactic acid bacteria, but lactobacillus in comparison to other species were predominant. Because of the preparation the chal from raw camel milk, saniting program should be conducted. It is strongly recommended that the behavior and presence of lactic acid bacteria even pathogenic microorganisms studied in raw camel milk and be compare with chal, also genotypic characterization need to conducte for more accurate identification of isolated lactic acid bacteria from chal.

Micro-organisms are important in dairy products. One of the most important groups of acid producing bacteria in the dairy industry is the Lactic Acid Bacteria (LAB) which is used in making starter culture for dairy products. The proper selection and balance for starter culture is critical for the manufacture of fermented products of desirable texture and flavour.

\section{Acknowledgment}

The authors would like to acknowledge the financial support of the Iran National Science Foundation for their interest in and support of this research.

\section{References}

1. Lhoste $F(2004)$ Lait de chamelle pour l'Afrique. Atelier sur la filière cameline en Afrique, Niamey, Animal production and health, Publication FAO. Rome.

2. Lakosa II, Shokin VA (1964) Milk production. In: Camels. Science. Technical Agricultural Publ. Kolos. Moscow: 113-120. 
Citation: Yam BZ, Khomeiri M, Mahounak AS, Jafari SM (2015) Isolation and Identification of Yeasts and Lactic Acid Bacteria from Local Traditional Fermented Camel Milk, Chal. J Food Process Technol 6: 460. doi:10.4172/2157-7110.1000460

3. Grigoryants NN (1954) Composition of camel milk and Chal (Ru). 13: 41-45.

4. Rao MB, Gupta RC, Dastur NN (1970) Camels' milk and milk products. Ind J Dairy Sci 23: 71-78.

5. Wickerham LJ (1966) Validation of the species Pichia guilliermondii. J Bacteriol 92: 1269.

6. Rose $\mathrm{AH}$ (1987) Responses to the chemical environment.

7. Chomakov H (1990) Microbiological investigations of the milk and dairy products Sofia: Zemizdat, 65 (in Bulgarian).

8. Lodder J, Kreger-vanRij NJW (1952) The Yeasts: A Taxonomic Study, Amsterdam, North-Holland Publishing Company.

9. Savova I, Nikolova M (2002) Isolation and taxonomic study of yeast strains from bulgarian dairy products. Journal of culture collections 3: 59-65.

10. Spencer JFT Spencer DM (1997) Yeasts in natural and Artificial Habitats Ed. Springer: 11-33.

11. Spreer E, Mixa A (1998) Milk and Dairy Product Technology, CRC Press: 339-362.

12. Van Uden N, Windisch $S$ (1968) Candida friedrichii sp. n., a melibiosefermenting yeast. Antonie Van Leeuwenhoek 34: 270-274.

13. Fleet GH (1990) Yeasts in dairy products. J Appl Bacteriol 68: 199-211.

14. Jakobsen M, Narvhus $J$ (1996) Yeasts and their possible beneficial and negative effects on the quality of dairy products. International dairy journal 6 : 755-768.

15. Knoke M (1999) [Gastrointestinal microecology of humans and Candida] Mycoses 42 Suppl 1: 30-34

16. Czerucka D, Piche T, Rampal P (2007) Review article: yeast as probiotics Saccharomyces boulardii. Aliment Pharmacol Ther 26: 767-778.

17. Sargent G, Wickens H (2004) Brewers' yeast in C. difficile infection: probiotic or B-group vitamins. The pharmaceutical journal 273: 230-231.

18. Oh Y, Osato MS, Han X, Bennett G, Hong WK (2002) Folk yoghurt kills Helicobacter pylori. J Appl Microbiol 93: 1083-1088.

19. Lopitz-Otsoa F, Rementeria A, Elguezabal N, Garaizar J (2006) Kefir: a symbiotic yeasts-bacteria community with alleged healthy capabilities. Rev Iberoam Micol 23: 67-74.

20. Reid G (1999) The scientific basis for probiotic strains of Lactobacillus. App Environ Microbiol 65: 3763-3766.

21. DeRoissart H, Luquet FM (1994) Bacteries Lactiques Vol. 1 and 2. Uriage. Lorica.

22. Oyetayo VO, Adetuyi FC, Akinyosoye FA (2003) Safety and Protective effect of Lactobacillus acidophilus and Lactobacillus casei used as probiotic agent in vivo. Afr J Biotech 2: 448-452.

23. Gadaga TH, Mutukumira AN, Narvhus JA (2001) The growth and interaction of yeasts and lactic acid bacteria isolated from Zimbabwean naturally fermented milk in UHT milk. Int J Food Microbiol 68: 21-32.

24. Rashid M, Miyamoto T (2005) Quality Evaluation of Traditional Milk "Sahi" in Bangladesh. J Milk Sci 54: 29-36.

25. Marth EH (1978) Standard Methods for the Examination of Dairy Products. (14 ed.), American Public Health Association, Washington, D.C

26. Bradley RLJ, Amold E, Barbano DM, Semerad RG, Smith DE, et al. (1992) Chemical and Physical Methods. Inc: Standard Methods for the Examination of Dairy Products. Marshall R.T. (Ed).

27. AOAC (1990) Official Methods of Analysis. (15 ${ }^{\text {th }}$ edn.), AOAC, Arlington. VA

28. Suh SO, Zhang N, Nguyen N, Gross S (2008) Lab manula for yeast study. Meredith Blackwell. Mycology lab, Louisiana state university.

29. Moore KJ, Johnson MG, Mcclary SP (1998) Disk inoculums-solid medium method to test carbon and nitrogen assimilation by yeast isolates. Applied and Environmental Microbiology 54: 3185-3186.

30. Harrigan WF, McCane ME (1976) Labortary Methods in Food and Dairy Microbiol. London.

31. Akabanda F, Owusu-Kwarteng J, Glower RLK, Tano-Debrah K (2010) Microbiological characteristics of Ghanaian traditional fermented milk product. NuNu J nature and science 8: 178-187.
32. Sneath PHA, Mair NS, Sharp ME, Holt JG (1986) Bergays Manual of Systematic Bacteriology. Vol 2, Williams and Wilkins Co, Baltimore, MD, USA: 965-1599.

33. Wood BJB, Holzapfel WH (1995) The Genere of Acid Lactic Bacteria. (1 ${ }^{\text {st }}$ edt) Chapman, Hall, Blackie and professional.

34. Zourari A, Roger S, Chabanet C, Desmazeaud M (1991) Caractérisation de bacteries lactiques thermophiles isolées de yaourts artisanaux grecs. Souches de Streptococcus salivarius subsp. thermophilus. Lait 71: 445-461.

35. Torres-Lianez MJ, Vallejo-Cordoba B, Diaz-Cinco ME, Mazorra-Manzano MA and Gonzalez-Cordova, AF (2006) Characterization of the natural microflora of artisanal Mexican Fersco cheese. J. Food Control 17: 683-690.

36. Kelly WJ, Davey GP, Ward LJ (1998) Characterization of lactococci isolated from minimally processed fresh fruit and vegetables. Int J Food Microbiol 45 85-92.

37. De Man JC, Rogosa M, Sharpe ME (1960) A medium for the cultivation of lactobacilli. J Appl Bacteriol 23: 130-135

38. Abdel-Rahman I, Dirar H, Osman M (2009) Microbiological and biochemical changes and sensory evaluation of camel milk fermented by selective bacterial starter cultures. African J Food Sci 3: 398-405

39. Mathara JM, Schillingera U, Kutima PM, Mbugua SK, Holzapfel WH (2004) Isolation, identification and characterisation of the dominant microorganisms of kule naoto: the Maasai traditional fermented milk in Kenya. International journa of Food Microbiology 94: 269-278.

40. Kurtzman CP (1990) Classification and general properties of yeasts. In: The Yeasts, Biotechnology and Bioanalysis (Edu): H. Ver.

41. Gadaga TH (2001) The occurrence and diversity of yeasts in Zimbabwean traditional fermented milk and their potential for use as starter cultures. $\mathrm{PhD}$ thesis, Agricultural University of Norway, $A^{\circ} \mathrm{s}$, Norway.

42. Beukes EM, Bester BH, Mostert JF (2001) The microbiology of South African traditional fermented milks. Int J Food Microbiol 63: 189-197.

43. Mushtaq M, Iftikhar F, Nahar S (2007) Detection of yeast mycroflora from butter. Pak J Bot 39: 887-896.

44. Abdelgadir WS, Hamad SH, Moller PL, Jakobsen M (2001) Characterisation of the dominant microbial of Sudanese fermented milk Rob. International Dairy Journal 11: 63-70.

45. Narvhus JA, Gadaga TH (2003) The role of interaction between yeasts and lactic acid bacteria in African fermented milks: a review. J Food Microbiol 86 $51-60$

46. Teuber M, Geis A, Neve H (1986) Genus Lactobacillus. In: Bergeys Manual of Systematic Bacteriology. (8th Edn), Waverly Press Inc., Baltimore, M., USA.

47. Sharpe ME (1979) Lactic Acid Bacteria in the Dairy Industry. Journal, Society of Dairy Technology 32: 9-17.

48. Holt JG, Krieg NR, Sneath HA, Staley JT, Williams ST (1994) Bergey's Manual of Determinative Bacteriology. (Ninth ed) Williams and Williams, Baltimore.

49. Garritty GM, Bell JA, Lilbum TG (2004) Taxonomic Outline of The Prokaryotes Bergey's Manual of Systematic Bacteriology, ( $2^{\text {nd }}$ edn. $)$, Springer, Newyork.

50. Hardie JM (1986) Genus Streptococcus Rosenbach 1884. In: SneathPHA, Mair NS, Sharpe ME, Holt JG (eds) Bergey's Manual of Systematic Bacteriology, Vol. 2, Williams and Wilkins Co, Baltimore, MD, USA: 1043-1071.

51. Kandler O, Weiss N (1986) Genus Lactobacillus Beijerinck 1901. In: Sneath PHA, Mair NS, Sharpe ME, Holt JG (eds) Bergey's Manual of Systematic Bacteriology, Vol. 2, Williams and Wilkins Co, Baltimore, MD, USA 2: 1209-1243.

52. Mundt JO (1986) Lactic acid streptococci. In: Sneath PHA, Mair NS, Sharpe ME, Holt JG (eds) Bergey's Manual of Systematic Bacteriology, Vol. 2, Williams and Wilkins Co, Baltimore, MD, USA: 1064-1071.

53. Elgadi, ZAM, Gadir WSA, Dirar HA (2008) Isolation and identification of lactic acid bacteria and yeast from raw milk in Khartoum state (sudan). Research Journal of Microbiology 3: 163-168.

54. Anonymous (1974) Bergey's Manual of Determinative Bacteriology. $8^{\text {th }}$ Ed. Waverly Press, Inc. Baltimore, Md., USA.

55. Abu-Tarboush HM (1994) Growth behavior of Lactobacillus acidophilus and biochemical characteristics and acceptability of acidophilus milk made from camel milk. Dept Food Sci College of Agriculture, King Saud University, Riyadh, Saudi Arabia. 
Citation: Yam BZ, Khomeiri M, Mahounak AS, Jafari SM (2015) Isolation and Identification of Yeasts and Lactic Acid Bacteria from Local Traditional Fermented Camel Milk, Chal. J Food Process Technol 6: 460. doi:10.4172/2157-7110.1000460

Page 6 of 6

56. Sulieman A, Ilayan A, EIFaki A (2006) Chemical and microbiological traditional fermented milk products of Ethiopia. Int J Food Microbiol 68: 173-186.

57. Omar H, Halima Z, Nour-Eddine K (2007) Technologically important properties of lactic acid bacteria isolated from raw milks of three breeds of Algerian dromedary (Camelus dromedarius). Afr. J Biotechnol 6: 1720-1727.

58. Gonfa A, Foster HA, Holzapfel WH (2001) Field survey and literature review on traditional fermented milk products of Ethiopia. Int J Food Microbiol 68: 173186.

59. Ashmaig A, Hasan A, Ei Gaali E (2009) Identification of lactic acid bacteria isolated from traditional Sudanese fermented camel milk (Grriss). African Journal of Microbiology Research 3: 451-457.

60. Halm M, Lillie A, Sørensen AK, Jakobsen M (1993) Microbiological and aromatic characteristics of fermented maize doughs for kenkey production in Ghana. Int J Food Microbiol 19: 135-143.

61. Hamad SH, Dieng MC, Ehrmann MA, Vogel RF (1997) Characterization of the bacterial flora of Sudanese sorghum flour and sorghum sourdough. J Appl Microbiol 83: 764-770.
62. Chandan RC (1999) Enhancing market value of milk by adding cultures. J Dairy Sci 82: 2245-2256.

63. Anuradha S, Rajeshwari K (2005) Probiotics in Health and Disease. JIACM 6: $67-72$.

64. Gibson GR, Roberfroid MB (1995) Dietary modulation of the human colonic microbiota: introducing the concept of prebiotics. J Nutr 125: 1401-1412.

65. Nigatu A (2000) Evaluation of numerical analyses of RAPD and API $50 \mathrm{CH}$ patterns to differentiate Lactobacillus plantarum, Lact. fermentum, Lact. rhamnosus, Lact. sake, Lact. parabuchneri, Lact. gallinarum, Lact. casei, Weissella minor and related taxa isolated from kocho and tef. J Appl Microbiol 89: 969-978.

66. De Angelis M, Corsetti A, Tosti N, Rossi J, Corbo MR, et al. (2001) Characterization of non-starter lactic acid bacteria from Italian ewe cheeses based on phenotypic, genotypic, and cell wall protein analyses. Appl Environ Microbiol 67: 2011-2020.

67. Muyanja CM, Narvhus JA, Treimo J, Langsrud T (2003) Isolation characterisation and identification of lactic acid bacteria from bushera: Ugandan traditional fermented beverage. Int J Food Microbiol 80: 201-210. 